\title{
UN CUBANO EN LA CORTE DE LA RESTAURACION: LA LABOR INTELECTUAL DE RAFAEL MONTORO, 1875-1878
}

POR

\author{
LUIS MIGUEL GARCIA MORA
}

\section{INTRODUCCIÓN}

La figura de Rafael Montoro y Valdés es bastante conocida en la historiografía cubana. Encarnación de las virtudes patrias y conformador de la nacionalidad para unos, es para otros la representación máxima de una formación política anticubana y proespañola. Esta doble imagen se corresponde con dos momentos diferentes de la historiografía cubana. La historiografía anterior al 1959 verá en Rafael Montoro y en el autonomismo una vía evolutiva, paralela al independentismo, en la consolidación de la nacionalidad cubana: para ésta independentismo y autonomismo pretendían un mismo fin, y lo que les diferenciaba era el método a emplear para conseguirlo. Desde esta perspectiva se justifica la misión histórica del autonomismo y de sus principales líderes, entre los que ocupó un lugar destacado Rafael Montoro.

Con el triunfo de la Revolución Cubana en 1959 comienza a desarrollarse la Isla una nueva visión historiográfica, que pretende la reconstrucción de la historia nacional a la luz del marixsmo. A partir de este momento se produce, en primer lugar, una marginación de los estudios de carácter político, en beneficio de los que se abordan una temática socioeconómica, quedando por lo tanto los estudios sobre el autonomismo y sus componentes en un segundo plano. A esto hay que unir una nueva valoración de los acontecimientos y personajes de la historia de Cuba (1).

Proyecto financiado por la CICYT, Plan Nacional I + D AME90-0793.

(1) Sobre la historiografía en Cuba tras la Revolución de 1959 véase Carmen Almodóvar: "Historiografía realizada en Cuba después de la Revolución Castrista" (1959-1984)" en Revista de Indias, vol. XLIX, n 185, 1989, págs. 173. 191. Desde otra perspectiva Louis A. Píkl:., Jr., "Toward a New Future. from a New Past: the Enterprise of History in socialist Cuba" en Cuban Studies/Estudios Cubanos, Winter, vol. 15, n 1, 1985, págs. 1-13. 
Desde estos nuevos planteamientos, el autonomismo es considerado como un movimiento burgués y antirrevolucionario; sus principales miembros se guiaban exclusivamente por su interés de clase, lo que explica su actitud en la Guerra de Independencia Cubana defendiendo una postura proespañola y por tanto antinacional, que se continuará en la República al favorecer de forma permanente la ingerencia norteamericana en Cuba.

Estas distintas valoraciones historiográficas se sustentan en diversos estudios realizados sobre el Partido Liberal Autonomista y sus principales representantes. Centrándonos en la figura de Montoro, podemos afirmar que son abundantes los estudios que analizan su actividad política e intelectual, tanto en el período inmediatamente anterior a la independencia de Cuba (1878-1898), como en la República. Sin embargo aún no se ha abordado el estudio en exclusiva y de una manera sistemática de la estancia de Montoro en España, entre 1867-1878, etapa de conformación intelectual de político cubano (2).

El presente trabajo pretende cubrir esta carencia mediante el examen de la labor intelectual de Montoro en dicho período analizando los distintos artículos que publicó en dos de las principales revistas científicas de la época: Revista Europea (18741880) y Revista Contemporánea (1874-1907), completando esta visión sobre la labor intelectual del autonomista cubano estudiando su actividad en el Ateneo de Madrid, «reflejo más acabado de la cultura española, el palenque en el que se dan cita todas las escuelas, todos los sistemas, todas las direcciones del pensamiento nacional» (3).

El conocimiento de esta etapa de formación nos sirve para poder apreciar mejor la labor histórica desempeñada tanto por Rafael Montoro como por el partido que lideró en el último tercio del siglo XIX. Su filiación hegeliana, que para algunos autores impregnó al autonomismo, su admiración por el liberalismo británico, que fue doctrina en el Partido Autonomista y su rechazo a los métodos revolucionarios son algunos de los aspectos que están presentes en los artículos que escribió y en los debates en que participó. En otras palabras, tratamos de valorar cómo influyó esta etapa española de Montoro, -en la que era "un hombre ajeno a la política, un hombre de vivir reposado, un

(2) Para un análisis de los trabajos publicados sobre Rafael Montoro véase Bibliografía de Rafael Montoro y Valdés, compilada por José BARRIAI. Domín(iuez, La Habana, Biblioteca Nacional, 1952.

(3) Manuel DE LA Revilla, "Revista crítica" en Revista contemporánea, t. I, Madrid, 15-XII-1875, pág. 125. 
hombre de estudios y teorías" (4)—, en la posterior etapa cubana, en la que lo político es característico y el vivir reposado, de estudio y teorías, se tornan en turbulenta actividad política de oposición y denuncia del régimen colonial.

Como paso previo al análisis de su producción intelectual, consideramos necesario dar unos apuntes biográficos sobre nuestro personaje, así como establecer el contexto histórico en el que se desarrolló su labor.

\section{VIDA Y CONTEXTO}

Rafael Montoro nació en La Habana en 1852. Hijo de un rico hacendado y magistrado estudió en uno de los mejores colegios de la ciudad. El Salvador, que «fundado por José de la Luz y Caballero en 1848, sirvió de centro aglutinador y formador de la intelectualidad cubana de la época" (5).

Según José María Chacon, siguiendo un manuscrito del propio Montoro, por problemas de salud visitó Estados Unidos, Gran Bretaña y Francia, ingresando posteriormente en el Colegio Charlier de Nueva York. Allí vive, en palabras de Montoro, un duro ambiente, pero que le ofrece la posibilidad del dominio del inglés, de la literatura, a la vez que comienza a aficionarse por los temas políticos. Lee a Goethe, Larra, Kempis, Macaulay y la Biblia (6).

Regresa a Cuba cursando estudios en el Colegio San Francisco de Asís. En esta institución recibe clase de Antonio Zambrana y conoce a Raimundo Cabrera y Leopoldo Cancio, también alumnos del centro. Tanto Zambrana, como Cabrera y Cancio serán miembros prominentes del Partido Autonomista. Con la ayuda de Cabrera intentó publicar un periódico, El Pueblo Cubano. A su vez, colabora en el periódico del colegio, Crónica del colegio San Francisco de Asís, y participa en los debates, que sobre distintos temas organizaba Zambrana empezando a demostrar sus grandes cualidades oratorias.

Nuevos problemas de salud le hacen abandonar Cuba. De

(4) José María Chacón y Calvo, "Montoro y la generación del Autonomismo" en Rafael Montoro Ideario Aulonomista, La Habana, Publicaciones de la Secretaría de Educación, Dirección de Cultura, 1938, pág. 29.

(5) Pedro Pruna y Armando Garcia, El Darwinismo en Cuba. Madrid, CSIC, 1989, pág. 27.

(6) José María Chacón y Calvo, Discursos lédos en la recepción pública del Dr. José María Chacón y Calvo, La Habana, imprenta "El Siglo XX", 1945, págs. 16-17. 
nuevo viaja por Estados Unidos y Europa, y llega a España fines de 1867. En Madrid le sorprende la revolución de 1868 que, según él mismo refiere en el manuscrito antes citado, no le entusiasmó mucho. Respecto a la Guerra de los Diez Años, afirma que en un principio trató de organizarse con otros cubanos residentes en Madrid a fin de favorecer el movimiento independentista, sin conseguir ningún resultado. En estos primeros momentos de su etapa madrileña estudia bajo la dirección de Padre Catalá, que llegaría a ser obispo de Barcelona, quien le inicia en la filosofía de Balmes. A su vez comienza a acudir los debates de las Cortes.

En 1872 el padre de Rafael Montoro llega a Madrid, procedente de Isla de Pinos a donde había sido desterrado por su colaboración con las fuerzas independentistas. Para estas fechas la fortuna de la familia había desaparecido. Comienza a frecuentar el Ateneo de Madrid, así como a colaborar en distintas publicaciones de la Capital: El Norte, El Tiempo, Revista Europea y Revista Contemporánea, esta última fundada por el también cubano José del Perojo.

Perfectamente integrado en los ambientes intelectuales de la Restauración, el periodista y ateneísta Julio Burell reconocía en Rafael Montoro la condición de «leader» que «en las batallas con la derechan se entablaban en el Ateneo (7). En 1877 se le nombra vicepresidente de la Sección de Ciencias Morales y Políticas del Ateneo de Madrid, además de ser secretario de la Junta Directiva y de haber contribuido a formar la Asociación de Escritores y Artistas Españoles, de la que también fue secretario (8).

A la muerte de su padre en 1878 regresa a Cuba para hacerse cargo de los asuntos familiares, integrándose a su vez en el renacer político que experimentó la Gran Antilla tras el Zanjón. Participa en la fundación del Partido Liberal Autonomista y elegido diputado a Cortes en 1879, no llega a ocupar su escaño. Acaba la carrera de derecho (1884) y en 1886 vuelve a obtener un escaño, siendo reelegido en las elecciones de 1893.

En este período Rafael Montoro desarrolló una gran actividad política a favor de la reforma colonial. Se convierte en el gran ideólogo del Partido Autonomista. Manuel de la Cruz, estudiando el papel de Montoro dentro del partido, afirma que: «Montoro es

(7) Julio Burell, "Rafael Montoro" en La Opinión, año I, ne 52, Madrid, 22VI-1886.

(8) Antonio Cortón, "Gente Antillana" en Revista de España, no 129, Madrid, 1890, pág. 93. 
el monarca nato de la junta (se refiere a la Junta Central del Partido Autonomista, máximo órgano de la dirección del partido). $\mathrm{Su}$ palabra y su consejo pesan en las deliberaciones como la espada de Breno; raro es el que osa bajar con él a la arena» (9).

Además de su labor política colaboró con distintos periódicos y revistas, entre las que destacan El Triunfo, El País, Revista cubana, El Palenque Literario, La Autonomía, El Fígaro, etc. en donde combinó las preocupaciones políticas con otras de carácter científico, filosófico y literario.

Esta etapa se cierra con la Guerra de 1895 a la que Montoro, y los restos del Partido Autonomista, se opusieron permaneciendo así al lado del poder colonial. En el fugaz gobierno autonómico de 1898 desempeñó el cargo de Secretario de Hacienda.

Para Manuel de la Cruz es difícil valorar la tarea política realizada por Montoro. De esta manera considera que «su labor de político activo es mitad inédita, mitad pública; a la primera corresponden sus iniciativa en las luchas con el gobierno colonial y sus actos parlamentarios; a la segunda, sus actos menos ostensibles como diputado y el ejercicio de su influencia en el seno de la junta central». Concluye Manuel de la Cruz que no se podrá juzgar la conducta política de Montoro hasta que no se disponga de la historia completa del Partido Autonomista en la que se analice a este partido como organismo político cubano, como adversario de la reacción colonial y como partido de oposición en las Cortes españolas» (10).

Al cesar la dominación española en Cuba, Montoro queda momentáneamente desplazado de la vida pública. Con posterioridad desempeñará importantes cargos como son: embajador en Londres y Berlín (1902-1906), secretario de la Presidencia con los gobiernos de Menocal (1913-1921) y secretario de Estado con el gobierno Zayas (1921). Muere en La Habana en 1933, a la edad de 81 años.

Conozcamos ahora algunos datos sobre la España en la que Rafael Montoro desarrolló su actividad intelectual. Aunque llegó a España en 1867, los primeros frutos de su dedicación intelectual

(9) Manuel DE I.A Cruz, Cromitos cubanos. L.a Habana, Editorial Arte y Literatura, 1975, pág. 51.

(10) Idem, pág. 58. 
se dan en plena Restauración borbónica. Con anterioridad el joven cubano se había dedicado a estudiar derecho, ocupación que pronto abandonó por la filosofía. También demuestra un interés por los estudios de carácter histórico; Chacón afirma que por estas fechas emprendió ambiciosos proyectos de investigación, que no llegó a culminar, como fueron una Historia crítica de las Comunidades de Castilla y una Historia de la filosofía a la luz del sistema de Hegel (11).

Será a partir de 1875 cuando Rafael Montoro demuestre su madurez intelectual. Para estas fechas el proceso revolucionario iniciado en 1868 se había visto desplazado del poder. La burguesía progresista y revolucionaria que había gobernado España desde aquella fecha se ve sustituida por otra de carácter conservador, que frente a los ideales revolucionarios prefiere el mantenimiento del orden que reclama el desarrollo socioeconómico de España, vertebrado alrededor de una "burguesía agraria proveniente de la desamortización, (de) los viejos terratenientes que venían de la antigua nobleza feudal y señorial, y (de) unos capitalistas volcados al mundo financiero y comercial» (12). Se configura un régimen que tendrá en Cánovas a su "gran arquitecto" dándole sustento doctrinal a la Constitución de 1876 y articulación política el turno de partidos. Es un régimen dominado por una oligarquía de políticos, que aseguran su poder gracias al caciquismo imperante en la España rural de fines del siglo XIX.

Desde el punto de vista intelectual, el nuevo régimen viene acompañado de una nueva corriente: el positivismo. Si el krausismo fue el gran pensamiento de las fuerzas progresistas y democráticas de Sexenio, el positivismo será el sustento ideológico de la Restauración, en un fenómeno que según Diego Núñez, no sólo afecta a la élite dirigente del régimen, sino también a los sectores democráticos, que van abandonando posturas idealistas por planteamientos políticos más realistas (13). De esta manera enjuiciaba Manuel de la Revilla los nuevos aires que llegaban a las fuerzas políticas de progreso «Síntoma consolador, por cierto, la aparición de esta nueva democracia, no ya idealista, utópica, bullanguera e intransigente como la pasada, sino cuerda, mesu-

(11) Chacón y Calvo, [6], págs. 22-23.

(12) José Luis ABELLÁN, "La crisis contemporánea" en Historia crítica del pensamiento español, tomo 5/I, Madrid. Espasa Calpe, 1988, pág. 17.

(13) Diego NúÑEz RuIz, La mentalidad positiva en España: desarrollo y crisis, Madrid, Ediciones Tucar, 1975, pág. 12. Sobre la necesidad del positivismo en las fuerzas de la democracia, F. M. TuBINO, "La crisis de pensamiento nacional y el positivismo en el Ateneo" en Revista de España, n 47, Madrid, 1875, pág. 429. 
rada y razonable! Trabajos ha costado llegar a este punto, y liberarse de los funestos resabios del jacobinismo francés y del progresismo español, buscando la ley y la norma de la democracia en las enseñanzas de la ciencia seria, de la ciencia inglesa y alemana y en las lecciones de la experiencia y de la historia» (14).

Hacia 1875, el krausismo, sin jefe natural desde la muerte de Sanz del Río, es atacado por unos y por otros en todas las instituciones. La imbricación krausista con la Revolución de Septiembre pasa factura en la Restauración. En el ámbito académico, la "cuestión universitaria" les aleja de sus cátedras. En el Ateneo de Madrid, otro de sus antiguos cotos, tienen que defenderse no sólo de sus tradicionales enemigos, sino que tienen que hacer frente a la vez a los ataques de neokantianos y positivistas. El desplazamiento de los componentes de la escuela krausista de las instituciones hará que encuentren en «la Institución Libre de Enseñanza su cuartel general, para volver a salir a la palestra, ya en forma de institucionismo, con los liberales de Sagasta» (15).

En definitiva, el ambiente intelectual que se respiraba en España al inicio de la Restauración viene marcado por el paso del krausismo al positivismo, a través de lo que Abellán, basándose en Adolfo Posada, denomina el kausopositivismo, tendencia ecléctica producida por la transformación del krausismo en positivismo, ayudados por la filosofía de Herbert Spencer (16). El positivismo había arrancado al krausismo su etiqueta de progresista. A este respecto López Morillas considera que krausismo había perdido vigencia, resultando un movimiento inactual Afirma que los krausistas "no estaban al día, no marchaba en "la vanguardia del pensamiento", siendo ésta la peor acusación que se le puede hacer a la escuela de Sanz de Río, "cuando lo que apremiaba era sincronizar espiritual y materialmente a España con el resto de Europa"" (17).

El positivismo será objeto de debates en el Ateneo en los que participará Rafael Montoro; la crisis del krausismo provocará

(14) Manuel de la Revilla, "Revista crítica" en Revista contemporánea, t. IX, 15-mayo-1877. La cursiva, del propio Revilla.

(15) Antonio Ruiz Salvador, El Ateneo de Madrid (1835-1885). Londres Tamesis Book. 1971, pág. 130.

(16) Abellán [12], págs. 80-84 y 108-120. La importancia de Spencer en el paso del krausismo al positivismo consiste en que fue el filósofo británico "quien a través de la noción de lo incognoscible facilita la transformación de una filosotía con amplia base religiosa, como es el krausismo, a los planteamientos eminentemente materialistas del positivismo", pág. 81, (la cursiva es de Abellán).

(17) Juan López Morillas, El Krausismo español Perfil de una aventura intelectual Madrid, 2. ${ }^{a}$ ed. revisada, 1980, pág. 99, (las comillas son de López. Morillas). 
una polémica en las páginas de la Revista Europea, a la que no será ajena Rafael Montoro, y por último, la transformación del régimen político y los nuevos planteamientos de la política, también ocuparán los debates del Ateneo y las páginas de las revistas, en las cuales Rafael Montoro también expresó su opinión. Las siguientes líneas tiene por objeto estudiar la prolífica actividad del político cubano desarrollada en los ambientes intelectuales de los primeros años de la Restauración.

\section{EN LA «REVISTA EUROPEA»}

La Revista Europea (1874-1880) (18), junto con la Revista de España (1868-1896) y la Revista Contemporánea (1875-1907), son representativas de una democracia liberal, encarnada por los distintos intelectuales progresistas españoles, que tienen por objetivo la regeneración intelectual, política y social de la España de la época (19).

La Revista Europea fue fundada y dirigida por Ricardo Medina y Armando Palacio Valdés respectivamente. En sus páginas aparecen trabajos sobre distintos campos, destacando la filosofía, ciencias naturales y literatura en los que se muestran todas las tendencias filosóficas del momento (20). Iris Zavala pone de manifiesto la importancia del pensamiento hegeliano en la publicación, citando los trabajos de Castelar, Fabié y el propio Rafael Montoro así como la introducción de la filosofía neokantiana en España gracias a los artículos de José del Perojo (21). López Morillas observa en ella una preferencia por el racionalismo armónico, a la vez que en sus artículos están las firmas de

(18) Rafael MonToro, "La polémica sobre el panentheísmo" en Revista Europea, ne 77, Madrid, 15 agosto 1875, 246-252. Asimismo Rafael MonToro: "El movimiento intelectual en Alemania" en Revista Europea, $\mathrm{n}^{\circ}$ 86, Madrid, 17 octubre 1875, 630-639.

(19) Gisèle CazotTes, La presse periodique madrilène entre 1871 et 188.5, Montpellier, Centre de Recherche sur les Littératures Ibériques et Ibéroamericaines Modernes, Université Paul Valéry, 1982, pág. 74.

(20) Para un análisis cuantitativo de las tendencias de la Revista Europea debe consultarse la primera parte de la obra de Ignacio Delgado González, La "Revista Europea" y su significado filosófico, 1874-1879, Salamanca, Ediciones de la Universidad de Salamanca, 1983.

(21) Iris M. Zavala; Románticos y socialistas. Prensa española del XIX, Madrid, Siglo XXI, 1972, págs. 192-193. Otra versión de este trabajo en Iris M. Zaval.A (cord.): "La prensa ante la Revolución de 1868" en Revolución de 1868. Historia. Pensamiento. Literatura, Nueva York, Las Américas, 1970, págs. 270-310. 
algunos de los principales discípulos de Sanz del Río (22). Pero como también pone de manifiesto el estudio de Delgado antes citado, el núcleo doctrinal de la Revista Europea es el positivismo que triunfa a partir de 1875 y que hace de la publicación su órgano de expresión, observándose que «los principales colaboradores de la Revista Europea son filósofos y científicos positivistas, que forman en ella un "colegio invisible" o escuela no organizada, que canaliza, si embargo, la trayectoria ideológica de la revista» (23).

En las páginas de esta publicación tuvieron lugar algunas de las principales polémicas de la época. Quizás la más conocida sea la que enfrentó a Menéndez Pelayo, Pidal y Laverde, por un lado, frente a Salmerón, Revilla, Perojo y Azcárate, de otro, defendiendo los primeros la actividad científica española frente al parecer de los segundos que consideraban a la Inquisición y al absolutismo culpables del atraso de la ciencia en España (24).

Sin embargo a nosotros, para nuestro estudio, nos interesa más una discusión anterior que sirvió de base al primer artículo que Rafael Montoro publicó en la Revista Europea. Nos referimos al conocido debate que sobre el krausismo enfrentó a Ramón de Campoamor con Francisco de Paula Canalejas y Manuel de la Revilla, entre los meses de mayo y agosto de 1875 (25).

A la hora de comprender esta disputa no debemos dejar de tener en cuenta todo lo manifestado anteriormente sobre el final de la hegemonía intelectual del krausismo, así como la persecución de que es objeto por el nuevo régimen de la Restauración, que se concreta en la "cuestión universtaria" de 1875. En este contexto es donde el poeta Ramón de Campoamor lanza su ataque contra el krausismo y le acusa de panteísta en lo metafísico y de utilizar un lenguaje de difícil comprensión. A los ataques de Campoamor contestan dos antiguos krausistas ya desligados de la Escuela: Canalejas y Revilla. El primero trata de demostrar la superación del panteísmo por el krausismo mediante el panen-

(22) LÓPEZ MORILlas [17], pág. 188.

(23) Delciado Gonzáli: [20], pág. 19, (las comillas son de Delgado).

(24) La relación de los artículos en los que se puede seguir al polémica sobre la ciencia española está en Vicente CACHO VIU, La Institución Libre de Enseñanza, Madrid, Ediciones Rialp, 1962, pág. 341 (nota).

(25) Para seguir la polémica deben consultarse los tomos IV (marzo-junio 1875) y V (julio-octubre) de Revista Europea. Aportaciones críticas sobre el enfrentamiento en ABElláA [12], págs. 135-143; CACHO VIU [24], págs. 320-329; Ignacio Delgado González, "La polémica sobre el krausismo en la Revista Europea" en La Ciudad de Dios, vol. CXCV, n² 2, 1982, págs. 291-301 y López Morill.as [17], págs. 195-199. 
teísmo, por el cual, aunque todo tenga su razón de ser en Dios, no significa que todo sea Dios. Revilla centra su defensa del krausismo no en la excelencia filosófica de la escuela, sino en que no le parece oportuna la actitud de Campoamor, al atacar en este momento a los krausistas, que por circunstancias políticas no pueden defenderse (26).

Todos los autores consideran que en la disucsión pesaron más los motivos políticos que los puramente filosóficos. López Morillas no duda en calificar la actitud de Campoamor de «intelectualmente indigna y moralmente reprobablen, en un intento de borrar antiguas veleidades revolucionarias y de congraciarse con el poder recién restaurado, del que se esperaba la más contundente reacción tras el asunto de la "cuestión universitaria" (27).

El artículo de Rafael Montoro cierra la polémica. Su objetivo no es terciar en la misma sino tratar algunos de los aspectos que dicho debate ha suscitado, desde una posición más objetiva y menos apasionada que los que en él directamente intervinieron (28).

A Montoro lo que le interesa es restar importancia a la filosofía krausista, a la vez que defiende los postulados hegelianos de los que es partidario. El primer aspecto que analiza es el concepto de panenteísmo, en el cual observa un rodeo que da Krause para evitar ser tachado de panteísta, cuando este problema ya lo había resuelto Hegel (29). Seguidamente toma en consideración los principios morales del krausismo, que defiende frente a los ataques conservadores, afirmando que «no hay ningún motivo

(26) La intervención de Manuel de la Revilla viene provocada por distintos motivos. En primer lugar, el escrito que Campoamor manda a la Revista Europea y que fue el origen de la controversia consistía en el prólogo que el propio Revilla le habia encargado para su obra Dudas y tristezas, desconociendo Revilla el contenido del mismo antes de que lo publicase la revista. En segundo lugar, Revilla había dado a conocer en la Revista Europea algunas cartas inéditas del introductor del krausismo en España y, por último, Manuel de la Revilla era hijo del íntimo amigo y protector de Sanz del Río, José de la Revilla. Por lo tanto, estas razones, además de su antigua comunión krausista, son las que le impulsan a defender a los discípulos españoles de Krause. Aún así, años más tarde Revilla no dudó en calificar la posición de los krausistas en esta discusión como inconveniente, intolerante y disparatada. Véase CACHO VIU [24], pág. 327.

(27) Vid. LÓPEZ MORILlas [17], pág. 199.

(28) En este aspecto coincidimos con lo manifestado por Ignacio DEciado GoNZÁlez, "El Pensador cubano Rafael Montoro su presencia filosófica en España" en Actas del IV Seminario de Historia de la Filosofía Española, Salamanca, Universidad de Salamanca, 1986, pág. 258. Aunque el objetivo de Delgado, según reza el título, es la presencia filosófica de Montoro en España, en realidad lo que aborda en el mismo son los artículos que Montoro publicó en la Revista Europea dentro de la línea de trabajo que el autor mantiene sobre esta publicación.

(29) Rafael MonTORo, "La polémica sobre el panenteismo" en Obras, t. II, vol. 1, La Habana, Cultural S.A., 1930, pág. 15. 
para alarmar con ella (se refiere a la moral krausista) a los conservadores tímidos y asustadizos" (30).

A continuación manifiesta su opinión sobre otra de las principales acusaciones de Campoamor, a saber: el oscurantismo del lenguaje de los krausistas. No está de acuerdo con el poeta. Considera que tanto en las obras de Krause como en las de Sanz del Río se puede encontrar un lenguaje "claro, correcto y elegante». Reconoce, sin embargo, que algunos pasajes son de difícil lectura, lo cual explica por el proceso de reforma del lenguaje que deseaba llevar a cabo Sanz del Río.

Termina Montoro haciendo unas reflexiones sobre lo que ha supuesto el krausismo en España, en las que se muestra más duro y menos tolerante que en párrafos anteriores. Así, considera que el krausismo aportó a la filosofía española una escuela filosófica, un método, una defensa del libre pensamiento y un sentido teológico de la filosofía. Pero para Montoro, «la escuela está disuelta y cada cual ha tomado un camino diferente» (31). Además resta originalidad al Sistema de Krause al considerarlo una derivación del de Schelling y una disidencia del de Hegel, concluyendo que "el krausismo es un mero incidente en la historia de la filosofía" (32).

Por todo lo expuesto anteriormente Montoro exhorta a los krausistas a que luchen al lado del idealismo contra el positivismo y el neokantismo, en defensa de la «religión verdadera y la verdadera filosofía" (33).

La primera conclusión que se puede sacar de este artículo es la filiación hegeliana de Rafael Montoro al que, posteriormente, algunos autores le han restado importancia e incluso la han llegado a negar (34). No negamos la filiación hegelina de Montoro, claramente expuesta tanto en éste como en otros artículos y en los debates en que participó, pero lo que nos interesa es intentar definir su posición ideológica a partir de su defensa del hegelianismo.

Los filósofos hegelianos de la Restauración han sido considerados como exponentes de un «fenómeno extemporáneo y conserva-

(30) Idem, pág. 21.

(31) ldem, pág. 27.

(32) Idem, pág. 28.

(33) Idem, pág. 28.

(34) Nos estamos refiriendo a Antonio Martínez Bello que en distintos trabajos "Montoro, Hegel y el Autonomismo" en Revista Bimetres cubana 1937; Origen y meta del autonomismo. Exágesis de Montoro ha negado la importancia del pensamiento de Hegel en Montoro, a la vez que lo ha rechazado como principio presente en el autonomismo. Contra estas apreciaciones está la obra de Antonio Sánchez de Bustamente y Montoro: La Ideologia Autonomista, La Habana, Imprenta de Molina y Cía, 1933. 
dorn; extemporáneo por considerarlo un movimiento superado por nuevas corrientes filosóficas, de signo positivista, y conservador por la defensa política que hacen de la Restauración borbónica (35). Esta interpretación no se puede sostener a poco que se conozca la constante crítica que ejerció Rafael Montoro hacia el régimen de la Restauración lo que le llevó, tanto a él como al Autonomismo, a vincularse con los sectores demócratas y republicanos de la Península (entre los que elegían sus representantes en las Cortes), a los cuales no se les puede conceptuar como defensores de la Restauración. No se puede, como hace Lacasta, asimilar políticamente a Montoro con Fabié, sólo por el hecho de que compartan unos principios filosóficos determinados (36).

La ubicación política de Montoro respecto de la Restauración hay que buscarla entre las fuerzas de progreso, esto es, a la izquierda del posibilismo de Castelar y por ello lejos de los defensores del régimen. Cierto es que al considerar a Montoro desde la óptica independentista, que a la postre triunfó en Cuba, se le puede catalogar como un defensor del dominio colonial español, al propugnar la autonomía frente a la independencia; pero no por ello se puede afirmar, sin más, que defiende el sistema ideado por Cánovas, para quien autonomía e independencia eran una misma cosa, que desarrollaban un mismo proceso: el de la pérdida de Cuba.

Si volvemos a la postura que Montoro mantiene en el debate, se confirma nuestro planteamiento. En el mismo defiende al krausismo de los ataques de Campoamor, quien sí es un defensor del poder conservador de la Restauración, tanto que llega a justificar la separación de los krausistas de sus cátedras. Montoro es todo lo contrario; si algo admira de krausismo es la defensa que hace de la libertad de pensamiento y los planteamientos morales que sólo pueden alarmar a "conservadores tímidos y asustadizos». Si hubiese sido un defensor del poder político, en estos momentos de decadencia del krausismo, hubiera vuelto decididamente sus planteamientos hegelianos contra él.

Por último, los contemporáneos a Montoro nunca le considera-

(35) José Ignacio Lacasta Zabalza, Hegel en España, Madrid, Centro de Estudios Constitucionales, 1984, pág. 192.

(36) Además, curiosamente, cuando Fabié era Ministro de Ultramar, los autonomistas decretaron el retraimiento electoral, con lo que se desvinculaban de la legalidad constituida. Por otro lado será Montoro uno de los encargados de mostrar a Fabié la oposición de los distintos sectores económicos de la colonia respecto a las relaciones comerciales que se mantenían con los Estados Unidos y que condujeron al Tratado de Reciprocidad de 1891. La oposición de Montoro a Fabié puede verse en Rafael MonTORO, "Rectificaciones históricas a Fabié" en Revista Bimestre Cubana, vol. XXII, La Habana, 1927, págs. 191-211. 
ron un hombre de la Resturación. Julio Burell escribe en 1886 todo lo contrario. Ve en el pensador cubano un hombre del Sexenio considerándole «uno de los que ha podido romper la malla de la oligarquía establecida, y que venga a su generación de once años de injusticias y olvidos». Antonio Cortón, recordando sus actividades ateneísticas, no duda en situarlo entre la «bulliciosa y democrática minoría». Finalmente el mordaz crítico Manual de la Revilla ve en Montoro un político de ideas avanzadas (37).

La segunda contribución de Montoro en la Revista Europea es la crítica que realizó del libro, Ensayos sobre el movimiento intelectual en Alemania, escrito por su íntimo amigo y compañero José del Perojo (38). En su análisis Montoro se enfrenta con otra de las nuevas corrientes de pensamiento: el neokantismo (39).

Se puede considerar a el neokantismo como una corriente

(37) Vid. Burell [7], CorTón [8], pág. 92 y Manuel dE LA Revilla, "Revista crítica" en Revista Contemporánea, t. IIl, Madrid, 15-mayo-1876.

(38) José del Perojo nació en Cuba en 1852, pero difícilmente podría llamársele cubano ya que hizo toda su vida en España, dedicándose a la filosofía, el periodismo y la política (fue diputado a Cortes por el partido autonomista). Estudió en la Universidad de Heildelberg (Alemania) en donde obtuvo el doctorado en filosofía. Allí, bajo la tutela de Kuno Fischer, aprendió a valorar el pensamiento de Kant, sumándose a la Escuela Neokantiana, que introdujo en España desde las páginas de la Revista Europea y principalmente desde la Revista Contemporánea que fundó y dirigió hasta 1879.

Posteriormente se dedica más a labores periodísticas y políticas. Fundó y dirigió La Opinión, El Nuevo Mundo y El Teatro. Entre sus obras destacan, a parte de las de carácter filosófico siempre centradas en Kant y el neokantismo, aquellas en las que aborda la problematica colonial como Cuestiones Coloniales (1885), Ensayos de política colonial (1883), etc. Es de destacar su participación en el Congreso Colonial de Amsterdem (1883), en donde sostuvo la tesis desarrollada en su libro Cuestiones Coloniales.

Falleció en 1907, en el Congreso de los Diputados en el que era representante por las Canarias.

Para una mayor información sobre José del Perojo debe consultarse: Diccionario de Literalura Cubana, t. II, Instituto de Literatura y Lingüistica de la Academia de Ciencias de Cuba, La Habana, 1984; Medardo VitiER, Las ideas y la filosofía en Cuba, La Habana, Instituto del Libro, 1970, págs. 443-453; Rafael Montoro [29], t. III, págs. 257-265; Nuevo Mundo, 29 octubre 1908; Antonio SÁnCHEZ de Bustamante y MonT(ORO, La filosofía clásica alemana en Cuba, 18411898. La Habana, Editorial de Ciencias Sociales, 1984, págs. 37-041; Álfonso Hernández Cata, "José del Perojo" en El Fígaro, La Habana, I diciembre 1907. Por último la íntima relación que a lo largo de sus vidas mantuvieron Perojo y Montoro, se puede rastrear perlectamente consultando la Colección de Manuscrilos de Rafael Montoro, tomo XXX, La Habana, Biblioteca Nacional José Martí, Sala Cubana.

(39) Para tener una visión de lo que supuso el neokantismo en el pensamiento español del siglo XIX es de obligada consulta: ABEL.ı.ÁN [12], págs. 120-130; LóPEZ MORILlas [17], págs. 85-105; NúNEZ RUIZ. [13], págs. 146-161 y CaCho [24], págs. 329-340. Por último, Rafael MONT(JRO, "Kant, el neokantismo y los neokantianos españoles" en Obras [29], págs. 99-129, publicado originalmente en la Revisla de Cuba en 1878. 
filosófica que pretende la vuelta al criticismo kantiano desterrando cualquier veleidad metafísica y procurando dar a la filosofía un nuevo objeto, que la relación con las ciencias particulares, las cuales la han desplazado en lo referente a la explicación de las cosas. En otras palabras, el neokantismo trata de ofrecer una nueva concepción del sistema de Kant, en medio de la nueva situación creada por el auge de las ciencias positivas. Para Ignacio Delgado el neokantismo "pretende superar, por una parte, el positivismo y el materialismo y, por otra, la filosofía especultiva romántica, a través de una consideración crítica de las ciencias y de una fundamentación gnoseológica del saber» (40).

En su artículo Montoro comienza valorando la influencia de la filosofía alemana en la Europa de la Restauración monárquica, en donde tras las terribles experiencias de la Revolución Francesa, se había encontrado en los especulativos sistemas alemanes poderosos auxiliares para salvar la base de la civilización europea, a saber: Dios y la libertad. Los grandes sistemas alemanes comenzaron a en Kant y culminaron en Hegel; Fitche y Schelling son aportaciones menores, al igual que Krause, de trascendencia en España y Bélgica. Pero según Montoro, el desarrollo filosófico alemán continúa y se precisa conocerlo, de ahí la necesidad del libro de Perojo, «uno de los representantes más inteligentes y laboriosos de la nueva generación, de esta generación educada en medio de los dramas y las tristezas y los increibles desastres de una revolución malograda" (41).

En el libro de Perojo se analizan distintos aspectos del movimiento intelectual alemán, por lo que en apariencia podría resultar un libro desigual, ya que en el mismo se mezcla la historio. grafía, la filosofía, la política y la antropología. Montoro encuentra el principio que da unidad al libro: el neokantismo de Perojo. Este principio lo presenta Perojo en el primero de los ensayos, "Kant y los filósofos contemporáneos», en donde proclama la vuelta a Kant. Montoro, partidario de Hegel se opone, al considerar que si la vuelta a Kant es para renovar y perfeccionar su sistema, también lo pueden pretender otros filósofos no conformes con los supuestos kantianos (42).

(40) Ignacio Delgado GonzÁlez, "Cuestionamiento y superación del pensamiento filosófico oficial en España durante el último cuarto del siglo XIX. Estudio de la Revista Europea (1874-1879) en Cuadernos Salmantinos de Filosofía, vol. IX, 1982, pág. 109.

(41) Rafael Montoro, "El movimiento intelectual en Alemania. Apuntes críticos sobre el libro del señor Perojo" en Obras [29], pág. 33.

(42) Vid. MONTORo [29], pág. 36. 
Planteados estos antecedentes, la necesidad de libro y el principio neokantiano que lo envuelve, el análisis de Montoro pretende "formar exacto juicio de las nuevas corrientes que invaden el terreno de la filosofía española». (43), en otras palabras, dar su parecer ante el momento intelectual por el que atravesba el país, marcado por la crisis del krausismo. Es un paso más allá respecto al artículo anterior, ya que en aquél el objeto era el análisis del pensamiento que se retiraba - el krausismo-, mientras que ahora es la consideración de una de las corrientes que se intenta imponer.

Montoro centra su análisis del neokantismo en los de los ensayos de Perojo: "Kant y los filósofos contemporáneos» y «El objeto de la filosofía en nuestros tiempos». Considera que es imposible frenar la filosofía en Kant, no se puede volver a él olvidando a los sistemas posteriores, que para Montoro no son más que una consecuencia del progreso de la filosofía, de la historia, contra lo que no se puede luchar. En terminología hegeliana Montoro manifiesta: «Toda historia es un desarrollo, y todo desarrollo existe a condición de que en cada momento sea una involución y una evolución al mismo tiempo. Y ésto es lo que sucedió en la nueva filosofía. Fichte presupone a Kant, Schelling presupone a Fichte y Kant, y Hegel presupone a los tres" (44).

Tampoco está de acuerdo con el objeto que los neokantianos atribuyen a la filosofía. Perojo, siguiendo a Wundt, establece que el objeto de la filosofía es explicar la efectividad de las otras ciencias, y a que en la explicación de lo que las cosas son, la filosofía se ha visto desplazada por las ciencias experimentales. La discrepancia de Montoro se presenta en dos planos. Primero el concepto de ciencias, ya que Montoro intuye que para Perojo ciencia no es más que experiencia, por lo tanto no lo puede aceptar, ya que el verdadero objeto de la ciencia reside en lo absoluto, lo cual es inteligible. En segundo lugar, la filosfía siempre tendrá un objeto al que nunca podrán llegar las ciencias: «El objeto de la filosofía es la verdad en su acepción más elevada, en el sentido de que Dios es la Verdad. Lo absoluto: he aquí el objeto de la filosofía; y ese objeto es real, lo real por excelencia» (45).

Seguidamente entra a considerar qué es el neokantismo como escuela. No niega a Kant la importancia que tiene dentro de la

(43) Idem, pág. 37.

(44) Idem, págs. 44-45.

(45) Idem, pág. 43. 
historia de la filosofía, pero distingue en el pensador alemán dos direcciones, "una crítica y negativa, y otra dogmática y positiva». Para Montoro los neokantianos se aferran mas a la tendencia negativa, reaccionan contra todo sistema especulativo y se comprometen con la dirección experimental y naturalista. Esto lo rechaza Montoro, pero no le preocupan en exceso los principios neokantianos que se intentan introducir, ya que considera que tarde o temprano el hombre volverá su mirada hacia los sistemas especulativos en busca de la verdad. En definitiva, concluye diciendo que si se vuelve a Kant, se volverá a los grandes sistemas posteriores a este filósofo (46).

Montoro se muestra tolerante con este pensamiento. Lo rechaza, pero le merecen respeto y simpatía los que intentan encauzar las corrientes filosóficas del momento. Defiende el libro de Perojo por encontrar en él ilustración, seria y libre indagación, amor a la verdad, convicción y pureza de motivos. Por ello considera que le libro de Perojo se debe recibir con «una cariñosa bienvenida, aunque no se piense como el autor, ni se aspire, por lo tanto, en las nobles tareas de la meditación a conseguir los mismos resultados y a prestar un servicio a las mismas doctrinas» (47).

Como en el artículo anterior la postura de Montoro es de una total comunión con los principos hegelianos, que le llevan a no reconocer nada que vaya más allá de los principios del idealismo absoluto y cae en algo que critica a Perojo, esto es: que a cada momento histórico le corresponde una determinada filosofía y el idealismo ya había perdido su momento histórico.

Por otro lado, en distintas partes del artículo se nota un cierto conservadurismo ideológico en el pensamiento de Montoro al defender como objeto superior de la filosofía a Dios; al declarar que la Revolución de 1789 fue un momento triste que dejó a Europa sin ideales, por lo cual se tuvo que recurrir a la filosofía alemana para crearse unos nuevos. Cierto conservadurismo, en definitiva, al afirmar que el neokantismo viene a consumar la desgracia de la filosofía. Es interesante comparar el artículo de Montoro con el de Revilla, quien considera el libro de Perojo indispensable si no se quiere convertir a España en una especie de China intelectual, aislada de la Europa y reducida a nutrirse

(46) Idem, págs. 48-49.

(47) Idem, pág. 52. 
de anticuadas fórmulas y decrépitas doctrinas» (48). Por decrépitas doctrinas entendía Revilla el krausismo y todos los sistemas de base metafísica posteriores a Kant, Hegel incluido.

La posición filosófica de Montoro estaba siendo superada por los nuevos aires que recorren la filosofía española; los conoce, los estudia, los compara con sus principios hegelianos, establece los principios de la civilización y los rechaza; pero el rechazo no es exclusivamente por el peligro que corren los valores tradicionales, ya que siempre defenderá la libertad de pensamiento como base de cualquier actividad intelectual, si no por su convencimiento de la superioridad de la filosofía hegeliana. De aquí arranca la admiración y aprecio de sus contemporáneos, los cuales sí se van adheriendo a los nuevos principios filosóficos. Montoro podrá defender una posición filosófica superada e incluso conservadora, por lo que no cabe en él, y es esto lo que admiran sus contemporáneos que hace que le incluyan entre los destacados de una nueva "generación ilustrada, independiente en sus juicios, ávida en su saber,... (que) comienza a iniciar un grande y fecundo movimiento" (49), lo que no cabe, repetimos, es la intolerencia y la intransigencia ante otras formas de pensar. En este mismo artículo que estamos analizando defiende que shay que ofrecer un testimonio de simpatía a todas las convicciones sinceras y a todos los que trabajan de buena fe por la cultura del espíritu humano" (50). Esta misma actitud es observada por Vitier cuando Montoro se enfrenta a la filosofía de Varona, adversario filosófico y político (51) y esta misma actitud explica que Montoro ayude a fundar y sea redactor jefe de la que será el órgano de expresión del neokantismo en España, Revista Contemporánea.

Como conclusión a la labor desempeñada por Montoro en la Revista Europea podemos afirmar que en la misma prima lo filosófico. En los dos artículos analiza la realidad de la filosofía española: estudia lo que se va en el primero y recibe lo que viene en el segundo. Coincidimos con Delgado al afirmar que estos dos artículos son una muestra de la ingente altura filosófica del

(48) Manuel DE L.A REVILL.A, "El neokantismo en España. Ensayos sobre el movimiento intelectual en Alemania por Don José del Perojo" en Revista de España, n 47, Madrid, 1875, pág. 146.

(49) Vid. DE LA REvilla. [47], pág. 10.

(50) Vid. MONTORO [29], pág. 52.

(51) Vid. Vitier [38], pág. 457. 
cubano Rafael Montoro, a la vez que nos descubre un pensador claro y profundo (52).

\section{EN LA «REVISTA CONTEMPORÁNEA»}

A fines de 1875 (15 de diciembre) aparece el primer número de la Revista Contemporánea (53), gracias a la dedicación de tres hombres: José del Perojo, director de la publicación, Manuel de la Revilla, redactor jefe encargado de la sección crítica y Rafael Montoro, también redactor de la revista encargado de analizar el movimiento literario extranjero, en un principio sólo inglés y norteamericano, además de contribuir con algunos artículos de crítica histórica, literaria y filosófica.

A diferencia de la Revista Europea, semanal, la Revista Contemporánea era quincenal. Con la salida de la revista se completa el panorama bibliográfico intelectual madrileño de la Restauración, que para esta época es tanto como decir español. La Revista Contemporánea fue respecto a la Revista España y Revista Europea, la de mayor duración llegando hasta 1907, pero como afirma Gisèle Cazottes el número de sucriptores de la publicación en su mejor época, no debió superar la mitad de los que tenía la Revista de España (54).

En la historia de la revista se pueden establecer distintas etapas. La más interesante es la primera, 1875-1879, en la cual la dirección de Perojo la convierte en "órgano de expresión de las

(52) Vid. Delgado González [28], pág. 262.

(53) Rafael Montoro, "Análisis y Ensayos" en Revista Contemporánea, t. VI, Madrid, 30 diciembre 1876, págs. 741-753; t. VII, 28 febrero 1877, págs. 533-535; t. IX, 15 junio 1877, págs. 245-251; t. X, 30 agosto 1877, págs. 506-515 y t. XI, 30 septiembre 1877, pags. 248-254. Rafael MoNTORO: "Crónica de literatura inglesa y norteamericana" en Revista Contemporánea, t. I, Madrid, 30 diciembre 1875, págs. 249-260; t. III, 15 abril 1876, 104-113 y t. V, 30 agosto 1876, págs. 235-246. Rafael MonTORo, "Los origenes de la Francia contemporánea. El Antiguo Régimen" en Revista Contemporánea, t. VI, Madrid, 15 noviembre 1876, págs. 122-126. Rafael Montoro, "Alfredo de Musset" en Revista Contemporánea, t. IV, Madrid, 15 abril 1876, págs. 19-51. Rafael MonTORO, "Un místico alemán. Juan Jorge Hamann" en Revista Contemporánea, t. VI, Madrid, 15 noviembre 1986, págs. 313-144. Rafael Montoro, "Cronica del Ateneo" en Revista Contemporánea, t. II, 1 febrero 1876, págs. 121-130. Rafael MONTORO, "Lucrecia Borgia rehabilitada" enRevista Contemporánea, t. I, 15 diciembre 1875, págs. Rafael Montoro, "Una defensa de María Tudor" en Revista Contemporánea, t. I, Madrid, 30 enero 1876, págs. 448-470. Rafael MonTORO, "La filosofía pesimista. El Sistema de Hartmann" en Revista Contemporánea, t. II, Madrid, 15 y 29 febrero, 1876, págs. 93-112 y 189-209, respectivamente.

(54) Vid. CazotTes [19], pág. 75. 
nuevas corrientes positivistas y neokantianas y atalaya abierta a los panoramas de la cultura europea, y singularmente alemana». Posteriormente la publicación es comprada por Julio de Cárdenas político sevillano ligado a Cánovas, «cambiando radicalmente la ideología de la publicación, con la que él (Perojo) había pensado cambiar el rumbo del pensamiento de su época" (55).

Desde sus páginas se intentó introducir todas las novedades del pensamiento europeo del momento, desde el neokantismo al evolucionismo, por lo que Abellán, citando a Glick, la considera el principal órgano de expresión del evolucionismo en España. En definitiva el objetivo de la revista era europeizar, en el sentido de modernizar, la cultura española de la época como paso previo a la creación de una cultura nacional propia. En este sentido la labor de la Revista Contemporánea guarda un gran parecido con la que posteriormente realizara la Revista de Occidente (56).

La labor de Montoro en la Revista Contemporánea es más variada. Aparte de la filosofía, la literatura y la historia son otros campos que preocupan al joven cubano, lo cual da ya a su obra, desde los primeros años, un cierto carácter enciclopédico.

Aunque, como acabamos de afirmar, la filosofía se ve superada por otros campos de interés, Montoro analiza para la nueva publicación las figuras de dos filósofos un tanto desconocidos en España: Juan Jorge Harmann (1730-1788) y Eduardo Von Hartmann (1842-1906).

El artículo sobre Hamann es consecuencia de la intervención de un religioso protestante en los debates que el Ateneo de Madrid había celebrado sobre el positivismo. Este religioso había rechazado los principios positivistas aplicando los conceptos místico-filosóficos de Hamann, los cuales eran desconocidos por la mayoría del auditorio. Este desconocimiento del pensamiento del místico alemán es lo que le empuja a escribir el artículo.

Comienza el mismo ofreciendo una gran cantidad de datos sobre la vida de Hamann, ya que consideraba que un buen conocimiento de su vida nos puede explicar su filosofía, la cual, según Montoro, no presenta un sistema claro y definido. Hamann acepta algunos principios kantianos, pero desprecia profunda-

(55) Sobre la dirección de Perojo al frente de Revista Contemporánea véase CACHo [24], págs. 336-337. Sobre la venta de la misma, el prólogo de Ramón de Paz a Revista Contemporánea, Colección de índiés de publicaciones periódicas, Madrid, 1950, pág. X.

(56) La cita de José Luis Abel.tán [12], pág. 95. La obra de T. F. Glick: Darwin en España, Barcelona, 1982, Sobre la similitudes de Revista Contemporánea con Revista de Occidente, Morit.l.As |17|, págs. 103-105. 
mente el pensamiento dialéctico y la primacía de la razón. A su vez, afirma la capacidad individual para poder desarrollar un sistema filosófico. Estas apreciaciones del místico alemán no gustan al joven hegeliano que, como al igual que hacía a la hora de juzgar al neokantismo, atribuye gran importancia a la sucesión de los sistemas filosóficos en la historia, defendiendo que el mejor filósofo es aquél que sabe comprender toda la filosofía anterior a la vez que crea una propia.

Destaca el carácter antisistemático del pensamiento de Hamann al afirmar que: "Hamann no quería oir hablar de filosofía sistemática. Todos sus escritos son una enérgica reivindicación del sentimiento personal y subjetivo, del hombre real y de sus conocimientos empíricos" (57). Considera esta postura consecuencia de su ortodoxia religiosa, que le llevan a señalar la identidad entre lo real y lo ideal desde los dominios de la teología, asegurando que todo tiene una doble realidad divina y humana.

Montoro se revela contra el planteamiento subjetivo de Hamann juzgando que: «Si el mundo obedece en verdad a las ideas, radican estas en una razón absoluta y se rigen por una dialéctica eterna, muy superiores sin duda a nuestra limitada razón y a la limitadísima dialéctica subjetiva a que atribuye vanamente nuestra credulidad un poder y evidencia que les faltan» (58).

Por lo tanto Montoro rechaza, desde su perspectiva hegeliana, la filosofía de Hartmann pero trata de buscarla una explicación al considerarle como parte de una corriente que, luchando contra el racionalismo de finales del siglo XVIII, pretendía defender la superioridad de la revelación divina frente a la razón.

La segunda contribución filosófica en la Revista Contemporánea consiste en comentar la obra de Eduardo Von Hartmann Philosopie des Unbewussten. Con este trabajo cumple uno de los principios fundacionales de la revista, como es el de dar a conocer las novedades filosóficas europeas, principalmente alemanas.

Vuelve a utilizar su concepción historicista de la filosofía explicando a Hartmann a partir de Kant y Schopenhauer. Aprecia en el primero un idealismo subjetivo y unilateral que reduce el conocimiento a lo fenomenal y relativo; esta es la base que abre el camino de la filosofía pesimista de Schopenhauer, al encontrar éste el nóumeno kantiano en la Voluntad. A la muerte de este último, Hartmann ocupa su lugar e introduce nuevos elementos

(57) Vid. MonTORO [29], págs. 68-69.

(58) Idem, pág. 72. 
en la filosofía de Schopenhauer que le llevan a establecer un sistema propio.

La doctrina de Hartmann es la filosofía del Inconsciente de carácter teleológico, al afirmar que son las causas finales las que explican las cosas. Para Hartmann la Voluntad es una fuerza mayor, no siendo sólo una intención consciente, sino inconsciente. Destácase el valor del instinto en la explicación de los fenómenos y desarrolla en su sistema el papel que juega el inconsciente en todos los aspectos de la vida: pensamiento, moral, historia, etc.

Para Montoro la filosofía de Hartmann se reduce a explicar todos los fenómenos del mundo material y espiritual al inconsciente, con lo cual no explica nada en realidad; se limita a reconocer que no se sabe de donde proceden los fenómenos del mundo.

Tampoco acepta las conclusiones pesimistas de la filosofía de Hartmann en las que la vida no es más que un cálculo entre el dolor y el placer, en el que pesa más el primero que el segundo. Montoro no reconoce ningún valor a las filosofías pesimistas, en su contra afirma que "descansan en una errónea consideración del placer y de la vida y que en vez de la melancolía abrumadora, que sólo puede ser útil para cooperar a la demolición del mundo de la Voluntad, sigue siendo el deber y la misión de los hombres luchar, buscar, encontrar y no rendirse" (59).

Estos dos trabajos nos aclaran aún más la posición filosófica de Montoro. Por un lado no puede aceptar el dogmatismo religioso de pietismo de Hamann, así como tampoco acepta el pesimismo de Hartmann. El porqué de la oposición a ambas tendencias está claro, en las dos la razón ocupa un segundo plano, frente a la revelación y la voluntad, lo que el hegelianismo de Montoro no puede aceptar. En su pensamiento se supera el dogmatismo religioso, la razón frente a la religión, pero no es capaz de comprender a las nuevas corrientes de sus épocas, condicionada por el desarrollo científico e industrial que reclama más filosofías de corte experimentalistas y materialista, a la vez que la crisis de valores del siglo empuja hacia fundamentaciones pesimistas.

A estos planteamientos opone un idealismo absoluto, que para Montoro no sería más que la culminación de la corriente racionalista de fines del XVIII a la que se oponía Hamann. Un idealismo que, como ya hemos manifestado, es la única filosofía capaz de salvar los principios fundamentales de la civilización europea

(59) Idem, pág. 209. 
occidental, Dios y la Libertad. Al afirmar la importancia de Dios, hace que Montoro ofrezca una interpretación religiosa de la filosofía hegeliana, al colocarle como el principal objeto de la filosofía (60), manifestándose una influencia religiosa que le venía de sus tiempo en el colegio Charlier de Nueva York, en donde el Kempis y la Biblia estaban entre sus lecturas favoritas. Por otro lado, la defensa del principio de la Libertad y la necesidad de la misma que manifiesta Montoro en sus planteamientos, coinciden con la defensa que hace del credo liberal en el ámbito político. De esta manera Montoro se nos presenta como un hombre ligado a los planteamientos político-filosóficos del liberalismo del siglo XIX. La incapacidad de evolucionar en su pensamiento a luz de las nuevas visicitudes históricas que se iban desarrollando a lo largo del siglo harán que sus posiciones, que lo ligaron en un tiempo a la Revolución del 1868, se hagan más conservadoras y como otros muchos hombres del Sexenios toma parte en la nueva situación política que se abre a partir de 1875 .

Otra de las ocupaciones de Montoro en la Revista Contemporánea es la de crítico bibliográfico. Esta labor la desempeña a través de dos secciones fijas de la revista Crónica de literatura inglesa y norteamericana y Análisis y ensayos. Con la primera de las secciones Montoro trata de poner de manifiesto la importancia cultural del mundo anglosajón, como una muestra de la admiración que el cubano siente por el desarrollo, que en todos los órdenes, se observaba en aquellos países; aspecto que lo opondrá a la realidad española.

De esta manera, Montoro estima que la importancia que para el pueblo británico tiene la ciencia hace que se escriban libros en los cuales se ofrecen introducciones populares de distintos temas de carácter científico. Lo paradójico, está en que si bien Montoro explica este género por la necesidad social que en Gran Bretaña se tiene de él, lo rechaza al considerar que la ciencia no debe ser ocupación más que de unos pocos. Otro aspecto que resalta en la comparación de la cultura española con la anglosajona es la importancia que se da en esta última a la figura del escritor, que no es más que un reflejo de la afición que a la lectura se tiene en aquellos países; ello le lleva a reconocer que la gran cantidad de bibliotecas existentes ayudan a la mencionada afición. En otras palabras, la grandeza de la producción intelectual anglosajona vendría explicada para Montoro por el grado de educación de sus sociedades.

(60) Vid. Lacasta Zabalza [35], pág. 221. 
La sección la divide temáticamente en seis partes: religión, filosofía, historia, política, ciencia y literatura. Hay que destacar la gran cantidad de obras que reseña, por lo que debía estar muy al corriente de todo el movimiento cultural anglosajón. Raimundo Lazo afirma que esta sección de Montoro «es un trabajo útil y de mérito dentro de su clase, nutrido de referencias informativas que podían interesar a los autores de lengua inglesa en la época en que se escribió dicha crónica" (61).

En Análisis y ensayos no muestra ninguna predilección por el movimiento cultural de un determinado país, analizando, eso sí, las distintas novedades editoriales europeas. Respecto a la sección anterior se centra más en los temas literarios, históricos o políticos, en cuyas críticas, más extensas, se observa el mismo estilo, el predominio de la ubicación de la obra en el desarrollo histórico, a la vez que desentraña las ideas fundamentales del texto que reseña. Por último tan sólo queremos señalar que en su oficio de bibliógrafo Montoro pone de manifiesto su ideario político, de interés para poder explicar su posterior actividad pública en Cuba.

Así, por ejemplo, en junio de 1876 dedica su sección al libro del italiano Domenico Di Bernardo La administracion local en Inglaterra, Escocia e Irlanda. Con esta crítica Montoro expresa su admiración por el sistema político británico, que por las mismas fechas estaba defendiendo en la Sección de Ciencias Morales y Políticas del Ateneo de Madrid. Ese culto a lo británico, en línea con el reformismo cubano del siglo XIX personificado en Saco y en su Paralelo de la Isla de Cuba y algunas colonias inglesas, será uno de los motivos que le hagan defender la vía reformista frente a mecanismos revolucionarios. De esta forma afirma que son «inmensas las ventajas de los países que saben encaminar su historia por fáciles senderos para que, avanzando sin cesar, y no de un golpe, las reformas que hacen sean las que necesitan y pueden realizar en cada tiempo; única manera de que, por prematuras, no resulten ineficaces, o por repentinas, no se vuelvan a perturbadoras" (62).

A continuación expone ideas que dos años después van a ser la bandera del ideario autonomista. La primera de ellas la educación del pueblo como un paso previo para la descentralización; un medio de prepararle para las reformas y que estas no caigan

(61) Raimunclo LAzo, "Algunas consideraciones sobre la crítica literaria de Montoro» en Revista Bimestre Cubana, vol. XXVIII, La Habana, 1931, pág. 346.

(62) Vid. MONTORO [29], págs. 241-2. 
en el olvido. Otro principio del ideario autonomista que nos adelanta Montoro en su crítica del autor italiano es la de autonomía, tal y como posteriormente la entendió el autonomismo cubano: «la descentralización debe dar a toda la localidad el gobierno de sí misma, más que sin que por esto se debilite ni se ataque la unidad y fuerza del estado" (63).

Las libertades necesarias y el sistema representativo, como garantía de la libertad y la soberanía del pueblo, es otra de las ideas del programa autonomista que manifiesta Montoro. Finalmente la defensa de la aristocracia británica como clase patriótica, inteligente y liberal que a la vez es «la clase que representa, la propiedad, las tradiciones nacionales o el mérito", nos recuerda a la defensa que el partido autonomista hace de la aristocracia cubana del azúcar.

La defensa de una determinada clase de la sociedad y el derecho político que reconoce a esta frente a las demás nos pone de manifiesto los límites de los principios demócrata liberales de Montoro, que acepta la soberanía del pueblo pero rechaza lo que para él son exgerados igualitarismos. Esta misma tesis la encontramos en la crítica que hace de la obra L'Etudiant del político e historiador francés Jules Michelet, en donde condena el igualitarismo del autor francés (64).

Por último en otra de sus reseñas, la que realiza de la obra de Albert Bolles El conflicto entre el capital y el trabajo, aboga por la libertad del capital frente al Estado; defiende la no intervención en la economía, al considerar que el capital tiene su propia ley, la iniciativa individual, para invertirse de manera productiva. Califica de socialista cualquier tipo de intervención del Estado y por tanto la rechaza (65).

Finalmente, Montoro también escribió algunos artículos de carácter histórico y literario para la Revista Contemporánea. En lo literario tenemos su trabajo sobre el poeta francés Musset, en donde explica la producción literaria del galo por el romanticismo de su obra. En definitiva el trabajo es un largo recorrido por la vida y la obra de Musset, en el que se destaca la figura de él como un hombre de su siglo, que canta al mismo, con gran originalidad y talento. Raimundo Lazo ve en esta obra un estudio

(63) Idem, pág. 244.

(64) Rafael Montoro, "Análisis y ensayos" en Revista Contemporánea, t. X, Madrid, 30 septiembre 1877, pág. 253.

(65) Rafael MONTORO, "Crónica de literatura inglesa y norteamericana" en Revista Contemporánea, t. V, Madrid, 30 agosto 1876, págs. 241-242. 
de juventud de Montoro interesante por la abundancia de noticias, por la novedad de la crítica y por el valor de la forma (66).

En los artículos de índole histórica se observa siempre el misno esquema: como pretexto del comentario de una obra de reciente publicación, Montoro se centra en el estudio del período que en el mencionado libro se analiza. De esta manera los trabajos "Lucrecia Borgia rehabilitada" y "Una defensa de María Tudorn no son más que comentarios ampliados a las obras que, sobre el mismo tema, habían escrito Gregorivius y Piggot (67).

Ambos trabajos muestran un mismo procedimiento. En primer lugar se nos ofrece un amplio contexto histórico, en el que posteriormente se enclava al personaje. Después, se centra en el personaje y explica todo su comportamiento por el marco histórico en el que desarrolla su actividad, para concluir, en ambos casos, en la necesidad de la revisión histórica que huya de tópicos y lugares comunes y que a la luz de nuevos documentos nos pueda dar el verdadero talante histórico del personaje estudiado.

De esta forma en su artículo sobre Lucrecia Borgia considera que todos los deformados juicios históricos que sobre la perversidad y malicia del personaje se ha realizados, son explicables por la corrupción política que se vivía en Roma en tiempos del Papa Alejandro VI. Lo mismo sucede con María Tudor. En el caso de la reina inglesa todo se explica por el fanatismo religioso que enfrentó a católicos y anglicanos en el siglo XVI. Los actos de María Tudor como el asesinato de Juana Grey o las persecuciones religiosas, no lo explica como consecuencia de la maldad de la reina, sino por razones de Estado. Es interesante la consideración de Montoro sobre la influencia de Felipe II sobre María Tudor, culpando al rey español del fanatismo religioso de la reina inglesa, a la vez que le considera culpable de la decadencia de España (68). Por ello la vida de María Tudor le sirve para condenar lo que considera un mal histórico, el fanatismo religioso, del cual no es culpable uno u otro personaje, sino la época en que viven.

Finalmente dentro de la crítica histórica debemos incluir la reseña que para la Revista Contemporánea realizó Montoro del trabajo de Hipólito Taine El Antiguo Régimen. En este trabajo se observa su filiación hegeliana y sus principios de demócrata conservador, al cơndenar los excesos revolucionarios, que no

(60) Vid. LAZO [62], pág. 357.

(67) Vid. Rafael MonTORO [53] y [29], págs. 131-157 y 159-180.

(68) Coincidiendo con la postura que sus compañeros Perojo y Revilla mantuvieron en la conocida polémica sobre la ciencia española. 
supieron compender lo que había de legítimo en la tradición y en el Estado que destruyó la Revolución Francesa (69). Sin embargo, como también hará en el curso que sobre la Revolución Francesa preparó para el Ateneo, rechaza la visión negativa que Taine ofrece sobre el fin del Antiguo Régimen y justifica desde su historicismo que "cuando nos colocamos en el terreno de la filosofía de la historia, no podemos concebir mayor justificación para un hecho importante. La revolución fue necesaria: hubieran tenido que desmentirse las leyes históricas para que no se realizara. Conste así para su gloria» (70).

En conclusión la tarea de Montoro en la Revista Contemporánea está muy en relación con el espíritu con que se fundó: reflejar la cultura europea de la época. Ello le lleva a analizar tanto la filosofía de Hartmann, como las últimas novedades bibliográficas del continente. En sus trabajos se siguen observando las formas hegelianas que ya apuntaban en la Revista Europea, así como unos planteamientos políticos que pasan por los principios de una democracia liberal conservadora, que la llevan a defender la libertad y los derechos de pueblo, a la vez que condena igualitarismos extremos, defendiendo la capacidad de dirección política de la burguesía, frente a otras clases.

\section{EN EL ATENEO DE MADRID}

No podemos terminar este trabajo, sobre las actividades intelectuales de la primera estancia española de Rafael Montoro, sin hacer algunas referencias a la participación del intelectual cubano en los debates que por aquellas fechas se realizaban en el Ateneo (71), que fueron los que le dieron fama en los ambientes

(69) Vid. MONTORo [29], pág. 257.

(70) Idem, pág. 259 (la cursiva es nuestra).

(71) Los debates en los que participó Montoro en el Ateneo son: Ventajas e inconvenientes del realismo en el arte dramático y con particularidad en el teatro contemporáneo (1875): Si es cierto que las tendencias positivas de las ciencias físicas y exactas deben arruinar las grandes verdades sociales, religiosas y morales sobre la que las sociedad descansa (1875-76); ¿Se halla en decadencia el teatro español? Si se halla ¿por qué medios pudiera procurarse su regeneración? (1876); ¿Son necesarios los partidos políticos? Caso de serlo ¿a qué principio a de someterse su organización? (1876); ¿Debe la Gran Bretaña el carácter a la vez estable y progresivo de su actual civilización a la constitución politica? (1876-77): Estado actual de la poesía lírica en España (1876-77); La poesía religiosa en España (1887). Aparte de estos debates hay que mencionar el curso que sobre La Revolución Francesa y sus historiadores le encargó la dirección del Ateneo, pero que no llegó a impartir. 
culturales del Madrid de la Restauración. No hay que olvidar que Montoro fue vicepresidente de la sección de Ciencias Morales y Políticas y secretario de la Junta Directiva y que será por su labor ateneísta por la que se le recordará cuando vuelva a España como diputado del partido autonomista.

Son muchos los autores que - desde Labra a la actualidadhan puesto de manifiesto la importante labor cultural desempeñada por el Ateneo en el siglo XIX (72). No se puede comprender el desarrollo intelectual e incluso político de la España del siglo pasado sin valorar uno de sus principales escenarios: el Ateneo de Madrid, en el cual se pone "en relación el pensamiento y el arte, la reflexión política y la erudición, el debate doctrinal y la emoción poética, en un permanente oficio de portavoz de todas las inquietudes intelectuales contemporáneas" (73).

El Ateneo de los primeros tiempos de la Restauración se caracteriza por la vuelta a sus salas de los antiguos demócratas liberales que las habían abandonado en busca del cargo político a partir de 1868. De esta manera se cumple uno de los principios que tanto Labra, como Manuel de la Revilla y otros ateneístas contemporáneos señalan en sus estudios, a saber que "la vida política en España y la vida del Ateneo están en razón inversa", por lo que refiriéndose a estas fechas Labra señala que las tendencias revolucionarias «invadieron» el Ateneo mostrando una viveza que constrastaba con la tónica conservadora general del país (74).

El Ateneo era el foro de discusión de la última teoría política, de la novísima filosofía y de la postrera producción literaria. En sus secciones se discutía de todo y por todos, sin los exclusivismos que se apreciaban en los estamentos de la cultura oficial, más

(72) Rafael María DE LABRA, El Ateneo de Madrid, Sus orígenes, desenvolvimiento, representación y porvenir, Madrid, 1878. Rafael María DE LABRA, El Ateneo de Madrid, 1835-1905. Notas históricas, Madrid, Tipografía de Alfredo Alonso, 1906. Aportaciones más actuales en Francisco Villacorta Baños, Burguesía y cultura. Los intelectuales españoles en la sociedad liberal, 1808-1931, Madrid, Siglo XXI, 1980 y sobre todo El Ateneo científico, literario y artístico de Madrid (1885-1912), Madrid, Centro de Estudios Históricos (CSIC), 1985. Finalmente, RuIz SALVADOR [15].

(73) Francisco Vill.acorta Baños, "Cultura y sociedad en el Madrid del siglo XIX" en Visión histórica de Madrid (siglos XVI al XX), Madrid, Colección Torre de los Lujanes, Real Sociedad Económica Matritense de Amigos del Pais, 1991, pág. 264.

(74) Manuel DF: I.A RE.VII.L.A, "Revista crítica" en Revista Contemporánea, t. I, Madrid, 15 diciembre 1875, pág. 125. Rafael María DE. Labra [72] El Ateneo... Notas históricas, pág. 43. 
concretamente en la Universidad, en donde con la libertad de cátedra, se había acabado con la libertad de pensamiento.

Rafael Montoro tuvo una participación muy activa en el Ateneo de estos años. Allí discutió sobre las últimas tendencias de la filosofía, defendió el liberalismo político británico y trató de establecer su ideal estético, siempre acompañándose de una oratoria que en palabras de la Revista Europea era correcta, elegante y metódica, con la que ponía de relieve sus condiciones de orador académico (75).

Las actividades de Montoro en el Ateneo se centraron en las secciones de Literatura y Bellas Artes y Ciencias Morales y Políticas. En ambas le veremos defendiendo algunas de las ideas que ya hemos expuesto a lo largo de este artículo. La última contribución de Montoro a esta institución fue un proyectado curso sobre La Revolución Francesa y sus historiadores, que aunque no llegó a impartir, su estudio no puede obviarse en un trabajo como el que nos ocupa, ya que también es una parte de la actividad intelectual desarrollada por Montoro.

Entre 1875 y 1877 Montoro participará en cuatro debates en la sección de Literatura y Bellas Artes. En los dos primeros el tema es el mismo: el realismo su influencia en el teatro. El primero de ellos se desarrolla a partir de marzo de 1875 y en él se discute la influencia de la estética realista en el teatro, mientras en el segundo, un año después, pasaba por analizar la decadencia del teatro, sus causas y posible solución.

Como era de esperar, conociendo sus antecedentes hegelianos, Montoro rechaza el realismo en el arte que lo considera una muestra del momento histórico que se vive, caracterizado por crisis filosófica y religiosa, los peligros del orden moral, la inestabilidad de las instituciones y la inquietud en los espíritus. Montoro se muestra conservador y rechaza las novedades estéticas del realismo, al cual se considera un mero accidente histórico, y continúa defendiendo un idealismo absoluto para el cual el arte no es más que la representación de la idea.

La postura conservadora de Montoro contrasta con la de otros participantes en el debate, como Vidart y Revilla para los cuales el realismo no es más que la versión estética del positivismo en filosofía. Revilla considera imposible volver a una estética idealista en el teatro $\mathrm{y}$, haciendo gala de su credo neokantiano, propone una síntesis entre el realismo e idealismo como fórmula más adecuada por la que deba discurrir la producción teatral,

(75) Revista Contemporánea, n² 56, Madrid, 21 marzo 1875, pág. 115. 
rechazando el exagerado naturalismo, pero defendiendo la necesidad del realismo. Propone a los valores del siglo XIX -la libertad, la ciencia y el progreso-, como nuevos ideales estéticos que deben regir el teatro (76).

Respecto a la decadencia del teatro, asunto que discute la sección a partir de marzo de 1876, Montoro la achacará a la tendencia realista que en él se observa, mientras que para Revilla la decadencia es producto del divorcio existente entre la vida y la escena que debería reflejarla, por lo que reclama una estética realista, así como la intervención del Estado, como solución a la crisis teatral. Claro está, Montoro desde su acentuado liberalismo se opondrá a la intervención estatal en el teatro por que en ello ve el fin de la libertad teatral (77).

En los otros dos debates de la sección de Literatura en los que Montoro participa, se preocupa de defender tanto la poesía religiosa como la lírica. El debate sobre la poesía religiosa en España (marzo-junio 1877) le sirve de excusa para hacer una defensa de la estética hegeliana. Entiende la estética como la parte de la filosofía que se ocupa de lo bello, la cual se comenzó a desarrollar con Kant, pero que tiene su culminación más perfecta en Hegel. Para Montoro el arte es la libre representación de lo bello y esto es «manifestación sensible de la idea como principio absolutom. Desde esta perspectiva rechaza cualquier principio positivista referido a la estética y defiende la poesía religiosa, al ser la religión la representación interna del Absoluto, mientras que la representación externa es el arte (78).

Finalmente respecto a la poesía lírica (noviembre-diciembre 1876) lo que le preocupa a Montoro es que no se pierda la forma del poema por el fondo, frente a los que defiende una poesía de carácter didáctico o científico, lo cual rechaza al reconocer que el arte y la ciencia se desarrollan en esferas diferentes, llegando a afirmar que la poesía que pretenda expresar la ciencia deja de ser poesía (79).

(76) Los debates se pueden seguir en las reseñas que publicó la Revista Europea entre 21 marzo y 23 de mayo de 1875. Sobre la consideración del realismo como una consecuencia del momento histórico Núñez Ruiz. [13], pág. 71.

(77) Para seguir el debate sobre la decadencia del teatro Revista Europea y Revista Contemporánea de febrero a junio de 1876.

(78) Sobre la intervención de Montoro en el debate relativo a la poesía religiosa debe verse, además de las reseñas de Revilla en la Revista Contemporánea (marzo-junio 1877), el Boletín del Ateneo, n², Madrid, octubre de 1877, págs. 498-515.

(79) Para el debate sobre la poesía lírica véanse Revista Europea y Revista Contemporánea, entre noviembre y diciembre de 1876. 
La intervención de Montoro en los debates de la sección de Literatura y Bellas Artes del Ateneo de Madrid nos ofrece la faceta estética del insigne cubano, en la cual hace gala de los principios idealistas mamados de la filosofía de Hegel, desde los que se opondrá a la principal novedad de la estética del momento, el realismo. En otras palabras, las apreciaciones estéticas sobre el arte y la literatura de Montoro estaban pasadas de moda, ya que en el último tercio del siglo XIX se exige del arte que sea fiel retrato de la sociedad en la que se vive, más que representación de la idea, que le lleva a un romanticismo idealista y sin sentido que no se corresponde con una realidad social de claro talante positivista.

La primera intervención de Montoro en la Sección de Ciencias Morales y Políticas se produce a consecuencia del debate que sobre el positivismo celebró esta sección en su curso de 1875-76. Estas discusiones no son más que el reflejo de la crisis del krausismo y la sustitución por otras corrientes, englobadas todas bajo el adjetivo de positivistas, a la que nos hemos referido más arriba, en un intento de desentrañar la esencia misma del positivismo y sus consecuencias sociales (80).

Desde el principio se formaron dos bandos: metafísicos y antimetafísicos, configurando el primero hegelianos, krausistas y espiritualistas, frente a neokantianos y positivistas. Para los primeros, entre los que se encuentra nuestro protagonista, el positivismo es la negación de la ciencia, la moral, la religión y el derecho, criticándole el fuerte apego de la nueva tendencia a la experiencia y la inducción.

Las críticas de Montoro hacia el positivismo se fundamentan en la diversidad de tendencias que reconoce dentro del positivismo, algunas de las cuales se contradicen. El ejemplo claro es el neokantismo, que como continuador y actualizador de la filosofía de Kant, no se puede englobar dentro de la tendencia positivista, ya que con ello margina un aspecto fundamental de la misma, la moral, que el filósofo alemán explicó con arreglo a fundamentaciones metafísicas. En definitiva, la estrategia de Montoro, además de ver en el positivismo un peligro para los valores tradicionales

(80) El desarrollo de las discusiones se puede seguir en las críticas de Revilla y Montoro en Revista Contemporánea, de diciembre de 1875 a julio de 1876. También en la misma revista los trabajos de AzCÁRATE: "El positivismo en el Ateneo de Madrid", t. III, 30-IV-1876, págs. 351-367, en donde resume el debate "Positivismo y civilización" en Revista Contemporánea, t. IV, Madrid, 30-VI-1876, págs. 231-251 y 30-VII-1876, 465-499. Finalmente otra aportación contemporánea el trabajo de Vid. TuBINo [13]. 
de la sociedad, es poner de manifiesto la incoherencia de algunos de sus componentes, más concretamente el neokantismo, al considerar que no se puede ser kantiano y defensor del positivismo a un mismo tiempo (81).

Tras el positivismo, la sección pone a debate la necesidad de los partidos políticos y los principios a que debe obedecer su organización. En las discusiones se puso de manifiesto el talante conciliador de todas las tendencias del liberalismo, desde constitucionales a demócratas. En sus crónicas Revilla observa cómo se moderan los demócratas y cómo los constitucionales tienden a una mayor liberalización. En el debate Montoro defendió la legalidad de los partidos políticos y la teoría de las libertades necesarias, con los mismos argumentos que las defenderá dos años más tarde en el Casino de Güines explicando la doctrina del recién fundado, y todavía no autonomista, partido liberal (82).

Si en el debate sobre los partidos políticos vemos a Montoro adelantando los principios liberales en los que se sustentará el autonomismo cubano, cuando se trate de la constitución política de la Gran Bretaña manifestará por ésta el mismo entusiasmo que posteriormente demostrará el autonomismo por el régimen colonial británico (83).

En el ejemplo inglés verá Montoro uno de los principios básicos del partido autonomista cubano: la evolución lenta y gradual como manifestación más clara del desenvolvimiento del espíritu nacional. En otras palabras admira de la Gran Bretaña, en donde ve el secreto de sus sistemas políticos, en haber sabido «hermanar sin revoluciones el porvenir y el pasadon (84).

Más adelante afirma que el sistema representativo amplio, la responsabilidad de los gobernantes y los derechos del hombre son aplicables a cualquier sociedad y son las garantías mínimas para constituir la costumbre política de cualquier pueblo. Pues bien, estos principios, estarán presentes cuando en 1886 Montoro exponga, en su primer discurso parlamentario, el ideal de autonomía tal y como lo entiende el partido. De esta manera se aprecia cómo los

(81) Los juicios de Montoro sobre el debate en Mon'soro: "Crónica de Ateneo"

(82) Para este debate, Manuel DE la Revilla, "Revista crítica" en Revista Contemporánea, t. IV, Madrid, 30 julio 1876, págs. 374-377.

(83) Para el debate sobre la constitución británica Revista Europea noviembre de 1876 a febrero de 1877 y Revista Contemporánea diciembre de 1876 a junio de 1877. Sobre la participación de Montoro Boletín del Ateneo, $\mathrm{n}^{9} 1$, Madrid, marzo de 1877, págs. 27-34.

(84) Boletín del Ateneo [83], pág. 29 (el subrayado es nuestro). 
principios demócratas liberales de talante reformista que Montoro ya defendía en los debates del Ateneo, serán los mismos que años más tarde armen doctrinalmente al partido autonomista.

La intensa actividad ateneísta de Montoro culmina cuando en septiembre de 1876 la institución le designa para que se haga cargo de una cátedra desde la que dictar un curso. Para este fin, Montoro prepara un curso titulado La Revolución Francesa y sus historiadores. Este trabajo en palabras de Chacón, que fue quien lo descubrió y publicó a modo de apéndice de su discurso de entrada en la Academia de la Historia de Cuba es un «documento esencial para conocer el pensamiento de Montoro, su método de trabajo, su temperamento intelectual, la vasta formación de su cultura en los años mozos» (85).

El manuscrito que se conserva se corresponde únicamente con la lección inaugural de curso en la cual Montoro plantea una serie de preliminares antes de entrar en la problemática del curso: la Revolución Francesa por examen y comparación de sus distintos historiadores.

A este respecto comienza ofreciendo el verdadero significado de la Revolución Francesa, esto es, es el inicio de una gran revolución que todavía se estaba desarrollando. Es un fenómeno universal que acabó con el Antiguo Régimen, no sólo en Francia sino en toda Europa.

Otro preliminar interesante que establece Montoro es lo que él mismo denomina la teoría de las revoluciones, con la cual pretende establecer el significado histórico del concepto revolución por el que entiende la transformación violenta del orden establecido. La revolución sería para Montoro un proceso necesario marcado por el desarrollo del espíritu nacional de los pueblos. En este sentido, cuando un régimen político, que se justifica por la necesidad que de él tiene toda nacionalidad, pierde su necesidad, su destino es desaparecer y a través de proceso revolucionario, dar lugar a un nuevo régimen, más acorde con las nuevas circunstancias que provocaron el proceso revolucionario. Por ello Montoro considera inevitables a las revoluciones, llegando a ver en ellas el grado de vitalidad y grandeza de los pueblos.

A primera vista contrasta la defensa de la revolución que hace Montoro con su futura actuación política dentro del autonomismo, desde donde reclama el progreso lento y evolutivo. La contradicción no es tal si consideramos que Montoro cree que «todo régimen político se explica por las circunstancias a que

(85) Vid. Chacón y Calvo [6], pág. 25. 
responde y las necesidades que satisface». Cuando pierde su razón de ser es cuando se produce por una inevitable necesidad histórica la revolución. Por ello no es que Montoro esté de acuerdo con las revoluciones, sino con su inevitabilidad que es diferente. Así, la oposición al proceso revolucionario cubano debe explicarse, porque para Montoro y su partido el régimen colonial no había perdido su razón de ser y respondía a unas determinadas necesidades, las de su clase, sin valorar que el espíritu nacional, tan ponderado desde su óptica hegeliana, ya no residía en la burguesía azucarera, sino en sectores más amplios de la sociedad cubana, para los cuales el régimen colonial respondía a unos intereses que les eran ajenos, siendo por lo tanto inevitable la revolución.

La permanencia de Rafael Montoro en España se corresponde con la etapa de conformación intelectual del político cubano. Tuvo una intensa presencia en todos los ambientes culturales de la época defendiendo un idealismo absoluto de corte hegeliano, frente a los nuevos principios filosóficos que aparecen a fines del siglo XIX. La filiación hegeliana de Montoro es una constante tanto en los artículos de la Revista Contemporánea y Revista Europea, como en los debates del Ateneo, por lo que no se puede dudar, como se ha hecho, del hegelianismo del intelectual cubano. Otra cuestión es que se haga de la filosofía hegeliana un principio básico del partido autonomista, el cual explique la posición histórica del autonomismo contraria a la vía independentista, lo que es más discutible.

La defensa que Montoro hizo en esta etapa de posturas idealistas, que filosóficamente le acercan a los sectores conservadores, contrasta con sus planteamientos avanzados en política que le sitúan al lado de Labra, Perojo, Revilla y otros, dentro de las posiciones más conservadoras del liberalismo democrático, del que comparte la defensa de libertad, la soberanía del pueblo, pero del que rechaza los exagerados igualitarismos. Por ello ve en la constitución política de la Gran Bretaña el modelo político a imitar, en el que el orden social se complementa con la libertad, evitando la revolución. Estos serán principios básicos del ideario autonomista al que Montoro dedicó sus mejores años y que explica, junto con los intereses de clase que defendió el partido, el comportamiento político del autonomismo cubano, más que cualquier principio metafísico (86).

(86) En este aspecto compartimos parte de las lesis que Martínez. Bello expuso en su obra. Martíni:z BliLlo [34]. 